\title{
Target Site-Based Resistance to ALS Inhibitors, Glyphosate, and PPO Inhibitors in an Amaranthus palmeri Accession from Mississippi
}

\author{
Vijay K. Nandula1, Darci A. Giacomini², William T. Molin ${ }^{*}$ \\ ${ }^{1}$ United States Department of Agriculture, Agricultural Research Service, Stoneville, MS, USA \\ ${ }^{2}$ University of Illinois, Urbana, IL, USA \\ Email: *william.molin@usda.gov
}

How to cite this paper: Nandula, V.K., Giacomini, D.A. and Molin, W.T. (2020) Target Site-Based Resistance to ALS Inhibitors, Glyphosate, and PPO Inhibitors in an Amaranthus palmeri Accession from Mississippi. American Journal of Plant Sciences, 11, 1206-1216.

https://doi.org/10.4236/ajps.2020.118085

Received: June 16, 2020

Accepted: August 8, 2020

Published: August 11, 2020

Copyright $\odot 2020$ by author(s) and Scientific Research Publishing Inc. This work is licensed under the Creative Commons Attribution International License (CC BY 4.0).

http://creativecommons.org/licenses/by/4.0/ (c) (i) Open Access

\begin{abstract}
Extensive acceptance of glyphosate-resistant (GR) row crops coupled with the simultaneous increase in glyphosate usage has sped the evolution of glyphosate resistance in economically important weeds. GR Amaranthus palmeri populations are widespread across the state with some exhibiting multiple resistance to acetolactate synthase (ALS) inhibiting herbicides such as pyrithiobac. A GR and ALS inhibitor-resistant accession was also resistant to the protoporphyrinogen oxidase (PPO) inhibiting herbicide fomesafen. The PPO inhibitor resistance profile and multiple herbicide resistance mechanisms in this accession were investigated. In addition to fomesafen, resistance to postemergence applications of acifluorfen, lactofen, carfentrazone, and sulfentrazone was confirmed. There was no resistance to preemergence application of fomesafen, flumioxazin, or oxyfluorfen. Molecular analysis of the ALS gene indicated the presence of point mutations leading to single nucleotide substitutions at codons $197,377,574$, and 653 , resulting in proline-to-serine, arginine-to-glutamine, tryptophan-to-leucine, and serine-to-asparagine replacements, respectively. The resistant accession contained up to 87-fold more copies of the EPSPS gene compared to a susceptible accession. A mutation leading to a deletion of glycine at codon $210(\Delta \mathrm{G} 210)$ of PPO2 gene was also detected. These results indicate that the mechanism of resistance in the Palmer amaranth accession is target-site based, i.e., altered target site for ALS and PPO inhibitor resistance and gene amplification for glyphosate resistance.
\end{abstract}




\section{Keywords}

Amaranthus palmeri, ALS Inhibitors, Glyphosate, Palmer Amaranth, PPO Inhibitors, Resistance

\section{Introduction}

The collective attributes of glyphosate herbicide, from its systemic action to its nonselective, wide range of postemergence activity, has contributed to its broad appeal throughout the world in both crop and noncrop lands since its commercialization in 1974. With the introduction of glyphosate-resistant (GR) crops in the mid-1990s, glyphosate was used selectively and predominantly for weed control in GR crops without concern for crop injury. The widespread adoption of GR crops around the world has led to overuse of the herbicide and reduced crop rotation, which resulted in the evolution of several GR weed biotypes. As of May 2020, GR populations have been reported for 48 weed species worldwide [1], including Amaranthus palmeri (S.) Wat. (Palmer amaranth).

Before the commercialization of GR crops, acetolactate synthase (ALS) inhibiting herbicides were used extensively for weed management in crop and noncrop areas. A major downside to the widespread use of ALS inhibitors has been the rapid and extensive evolution of resistance in several grasses and broadleaf weed populations across the world. For example, within 5 years of introduction of chlorsulfuron, the first ALS inhibitor to be commercialized, Lactuca serriola L. and Kochia scoparia (L.) Shrad populations became resistant [2] [3] [4]. As of May 2020, 165 weed species have been documented to be resistant to one or more ALS inhibitors [1]. Among these resistant weed species are several Amaranthus spp. including $A$. palmeri.

Resistance to multiple herbicides, such as glyphosate and ALS inhibitors, has been documented in A. palmeri [5] [6]. Almost all populations of $A$. palmeri in row-crop growing areas of Mississippi are considered to be resistant to glyphosate and ALS inhibitors. Loss of glyphosate and ALS inhibitors severely hampered control efforts against $A$. palmeri, leaving very few chemical options, such as glufosinate labeled for use in glufosinate-resistant crops and protoporphyrinogen oxidase (PPO) inhibitors for row crop growers in the United States.

PPO inhibitor resistant $A$. palmeri populations have been reported in Arkansas, Illinois, and Tennessee [1]. Lack of control of A. palmeri with PPO inhibitors has been sporadic in Mississippi, but more consistent in the past 24 - 36 months. A. palmeri plants in a GR soybean field in Stoneville, Washington County, MS were individually treated with fomesafen, a PPO inhibitor, two times (two weeks apart) at $0.42 \mathrm{~kg} \cdot a \mathrm{i} \cdot \mathrm{ha}^{-1}$. Leaf tissue from 43 surviving plants was sampled and analyzed for the presence of a deletion mutation, $\Delta \mathrm{G} 210$ [7]. Only one of the 43 plants, referred to as PA-R hereafter, revealed the presence of the above mutation. The other 42 plants were not analyzed further. 
The objectives of this research were to 1) characterize the magnitude of resistance to fomesafen and putative resistance to glyphosate and selected ALS inhibitors; 2) determine cross-resistance to selected PPO inhibitors, applied preemergence (PRE) and/or POST; and 3) elucidate the physiological and molecular mechanism(s) of resistance to ALS inhibitors, glyphosate, and PPO inhibitors in the PA-R accession.

\section{Materials and Methods}

\subsection{Plant Growth and Herbicide Treatment Evaluations}

Experiments involving herbicide responses on $A$. palmeri seedlings were performed in a greenhouse at the Jamie Whitten Delta States Research Center of USDA-ARS in Stoneville, Mississippi. The greenhouse was set to $25 / 20^{\circ} \mathrm{C} \pm 3^{\circ} \mathrm{C}$ day/night temperature under ambient conditions. All molecular studies were conducted at University of Illinois, Urbana, Illinois. Seed from a wild type/susceptible $A$. palmeri accession, (susceptible to all major herbicide families, data not shown) designated as PA-S, was included in all experiments. PA-S seed was sown at a depth of $0.5 \mathrm{~cm}$ in plastic trays $(50 \mathrm{~cm} \times 20 \mathrm{~cm} \times 6 \mathrm{~cm})$ containing a commercial potting mix [formulated Canadian sphagnum peat moss, coarse perlite, bark ash, starter nutrient charge (with gypsum) and slow release nitrogen and dolomitic limestone (Metro-Mix 360, Sun Gro Horticulture, Bellevue, WA) and then watered. Two weeks after germination, $2.5-\mathrm{cm}$ tall seedlings were trans-planted into $8 \mathrm{~cm} \times 8 \mathrm{~cm} \times 7 \mathrm{~cm}$ pots containing the same potting mix.

PA-R plants were generated from a parent a male plant ( $A$. palmeri is dioecious with male and female reproductive organs developing on different plants) using a cloning procedure described before [8]. Briefly, an axillary branch, approximately $3 \mathrm{~cm}$ long, was cut from the stem and lateral leaves removed leaving 4 leaves per stalk. The cut end was lightly coated with Rootone rooting hormone (TechPac, Lexington, KY) and placed in moist growth media as above. The plantlets were kept in indirect sunlight for $3 \mathrm{wk}$, then transplanted into larger pots, and watered and fertilized as described before.

For PRE studies, the soil used in studies on herbicide effects on $A$. palmeri was a Bosket sandy loam (Bosket sandy loam, fine-loamy, mixed, thermic Mollic Hapludalfs Twenty-five seeds of PA-S were planted at a depth of $0.5 \mathrm{~cm}$ and covered with additional soil. Ten PA-R cloned plantlets were transplanted into each pot immediately after herbicide application. Pots were watered instantly after herbicide application to activate the herbicide and as needed thereafter. Emerged PA-S and transplanted PA-R seedlings that remained herbicide injury-free were counted 4 wk after treatment (WAT).

All herbicide treatments were applied using an air-pressurized indoor spray chamber (DeVries Manufacturing Co., Hollandale, MN) equipped with a nozzle mounted with 8002E flat-fan tip (Spraying Systems Co., Wheaton, IL) delivering $190 \mathrm{~L} \cdot \mathrm{ha}^{-1}$ at $220 \mathrm{kPa}$ to $A$. pameri plants that were 5 - to $10-\mathrm{cm}$ tall and had four 
to six fully expanded leaves. All herbicide treatments were evaluated for efficacy based on the following: percent control ratings $(0=$ no injury, $100=$ dead $)$ were recorded 3 WAT in studies with PPO inhibitors applied POST. PRE PPO inhibitor efficacy was measured as percent decrease in cumulative emergence of seedlings with an active growing point compared with a nontreated control and glyphosate and ALS inhibitors were evaluated by measuring above ground shoot dry weight 3 WAT. An individual plant represented one replication in POST treatments, whereas an individual pot with 25 seeds or 10 plantlets represented a single replication in PRE studies. There were 4 replications per treatment in all herbicide response studies and studies were repeated.

\subsection{Herbicide Dose Response}

PA-R and susceptible PA-S plants were treated with fomesafen (Reflex ${ }^{\oplus}$, Syngenta Crop Protection, Greensboro, NC) at 1/8X, 1/4X, 1/2X, 1X (0.42 kg.ai.ha $\left.{ }^{-1}\right), 2 \mathrm{X}$, $4 \mathrm{X}$, and $8 \mathrm{X}$ rates; glyphosate at 1/8X, 1/4X, 1/2X, $1 \mathrm{X}\left(0.84 \mathrm{~kg} \cdot \mathrm{ae} \cdot \mathrm{ha}^{-1}\right)$, and $2 \mathrm{X}$ for PA-S and 1/2X, 1X, 2X, 4X, and $8 \mathrm{X}$ for PA-R; ALS inhibitors: imazaquin (Scepter ${ }^{\oplus}$, AMVAC Chemical Corporation, Los Angeles, CA), pyrithiobac (no 8X) (Staple ${ }^{\oplus}$, Corteva Agriscience, Indianapolis, IN), and trifloxysulfuron (Envoke ${ }^{\oplus}$, Syngenta Crop Protection) were applied in same dose range as glyphosate with the $1 \mathrm{X}$ rate being $0.14,0.11$, and $0.015 \mathrm{~kg} \cdot \mathrm{ai} \cdot \mathrm{ha}^{-1}$, respectively. A non-treated control was included with each set of dose responses. A nonionic surfactant (Induce ${ }^{\varpi}$, Helena Chemical Company, Collierville, TN) at $0.25 \% \mathrm{v} / \mathrm{v}$ and a crop oil concentrate (Agri-Dex ${ }^{\oplus}$, Helena Chemical Company) at $1 \% \mathrm{v} / \mathrm{v}$ were included with all ALS inhibitors and PPO inhibitors, respectively.

\subsection{PPO Inhibitor Cross Resistance}

PRE herbicide treatments included flumioxazin at $0.11 \mathrm{~kg} \cdot \mathrm{ai} \cdot \mathrm{ha}^{-1}$, fomesafen at $0.43 \mathrm{~kg} \cdot \mathrm{ai} \cdot \mathrm{ha}^{-1}$, oxyfluorfen at $0.56 \mathrm{~kg} \cdot \mathrm{ai} \cdot \mathrm{ha}^{-1}$, and nontreated. POST herbicide treatments were acifluorfen, lactofen, saflufenacil, carfentrazone, and sulfentrazone at $0.56,0.22,0.09,0.04$, and $0.42 \mathrm{~kg} \cdot \mathrm{ai} \cdot \mathrm{ha}^{-1}$, respectively. A crop oil concentrate was included at $1 \% \mathrm{v} / \mathrm{v}$ with each treatment.

\subsection{Molecular Analysis}

To check for known target-site resistance mutations in the PPX2 gene, genomic DNA was extracted from eight PPO-inhibitor-resistant and two PPO-inhibitorsensitive A. palmeri samples using a modified CTAB protocol [9]. A TaqMan-based quantitative PCR approach was used to detect the presence of any $\triangle \mathrm{G} 210, \mathrm{R} 128 \mathrm{G}$, and R128M mutations in PPO2, following previously described protocols [10] [11]. These same ten samples were also checked for known mutations in the EPSPS and ALS genes. EPSPS gene amplification and EPSPS P106S mutation were detected via quantitative PCR and a derived cleaved amplified polymorphic sequences (dCAPS) assay, respectively, following previously described protocols [12]. The ALS gene was amplified using primers specific to the 
5' and 3' untranslated regions of $A$. palmeri (ALS-5UTR-F:

5'-CTTCAAGCTTCAACAATG and ALS-3UTR-R:

5'-CCTACAAAAAGCTTCTCCTCTATAAG). PCR reactions included approximately $100 \mathrm{ng}$ DNA, $5 \mu \mathrm{L}$ Taq polymerase (New England Biolabs, Ipswich, MA, USA), $1.0 \mathrm{mM} \mathrm{MgCl} 2,0.2 \mathrm{mM}$ each deoxyribonucleotide triphosphate (dNTP), and $0.1 \mu \mathrm{M}$ of the forward and reverse primers. The thermocycler protocol was as follows: denaturation for $5 \mathrm{~min}$ at $95^{\circ} \mathrm{C} ; 34$ cycles of $95^{\circ} \mathrm{C}$ denaturation for $30 \mathrm{~s}, 50{ }^{\circ} \mathrm{C}$ primer annealing for $30 \mathrm{~s}$, and $72^{\circ} \mathrm{C}$ extension for $2 \mathrm{~min}$; final extension step of $5 \mathrm{~min}$ at $72^{\circ} \mathrm{C}$. Each PCR product was run out on $1 \%$ agarose gel and the $\sim 2 \mathrm{~kb}$ band was excised and purified from the gel using a QIAquick Gel Extraction Kit (QIAGEN Inc., Germantown, MD, USA). The purified product was sequenced using an ABI BigDye Terminator v3.1 Cycle Sequencing Kit (Applied Biosystems, Inc., Beverly, MD, USA) using the forward and reverse primers (ALS-5UTR-F; ALS-3UTR-R) as well as a third primer to capture the middle of the ALS gene (ALS-F2: 5'-GTATCTTTCTAGGTTGCCTAAACC). The sequenced products were then purified and electrophoresed on an ABI 3730xl Capillary DNA Analyzer by the W.M. Keck Center at the University of Illinois. After trimming low-quality bases using Sequencher 5.4 software (Gene Codes Corp., Ann Arbor, MI, USA), the sequences were aligned and analyzed using CLC Sequence Viewer (QIAGEN Inc., Redwood City, CA, USA).

\subsection{Statistical Analysis}

Data from dose-response and cross-resistance studies were subjected to analysis of variance using the general linear model procedure in SAS 9.4 (SAS Institute, Cary, NC). Data from the two experiments were combined because there were no significant interactions between experiments. Nonlinear regression was used to define a three-parametric power equation $y=y_{0}+a x^{b}$ to relating the herbicide dose effects $(\mathrm{x})$ on shoot dry weight $(\mathrm{y})$, where $y_{0}$ is an asymptote, $a$ is a constant, and $b$ is the slope of the curve. Equation parameters were calculated with SigmaPlot 12.5 (Systat Software Inc., San Jose, CA). $\mathrm{ED}_{50}$ (effective dose to achieve $50 \%$ control) and $\mathrm{GR}_{50}$ (dose required to reduce shoot dry weight by $50 \%)$ estimates were derived from curves fit in SigmaPlot at 50\% control or reduction in shoot dry weight. In the cross-resistance experiment, means were separated using Fisher's protected LSD at $\mathrm{P}=0.05$.

\section{Results and Discussion}

\subsection{Fomesafen Dose Response}

Response of PA-R and PA-S plants to fomesafen dose is represented in Figure 1. The $\mathrm{ED}_{50}$ values of PA-R and PA-S for fomesafen were 3.30 and $0.06 \mathrm{~kg} \cdot \mathrm{ha}^{-1}$ indicating that the PA-R accession is 55-fold more resistant to the herbicide compared to PA-S. This level is higher than the 6- to 21 -fold resistance reported in certain A. palmeri populations from Arkansas populations [9]. 


\subsection{Glyphosate Dose Response}

Response of PA-R and PA-S plants to glyphosate dose is represented in Figure 2. The $\mathrm{GR}_{50}$ values of PA-R and PA-S for glyphosate were 7.55 and $0.07 \mathrm{~kg} \cdot \mathrm{ha}^{-1}$ indicating the PA-R accession is 108 -fold more resistant to the herbicide compared to PA-S. Earlier reports of $A$. palmeri biotypes resistant to glyphosate from Mississippi were only 15 - to 18 -fold [6].

\subsection{ALS Inhibitors Dose Response}

Figures 3-5 represent response of PA-R and PA-S plants to increasing doses of pyrithiobac, imazaquin, and trifloxysulfuron, respectively. The $\mathrm{GR}_{50}$ values of PA-S were $0.006,0.0012$, and $0.0008 \mathrm{~kg} \cdot \mathrm{ha}^{-1}$ for pyrithiobac, imazaquin, and trifloxysulfuron, respectively. Similar GR50 values could not be assessed for the PA-R accession because the chosen nonlinear regression model did not fit the dose response. This was most likely due to the reduction in shoot dry weight being $0 \%, 0 \%$, and $33 \%$ of the nontreated control with pyrithiobac, imazaquin, and trifloxysulfuron, respectively, even at the highest rates applied. Since the $\mathrm{GR}_{50}$ value estimates for the PA-R accession would seemingly lie outside the dose range, it would be more accurate to report $\mathrm{R} / \mathrm{S}$ ratios as greater than a certain value based on the highest tested dose. This approach is frequently followed when resistance to a herbicide has already been widely reported and resistance is confirmed in a study followed by additional research and analysis. Therefore, the reported R/S ratios were based on extrapolated data and constrained to fit within the accuracy of their estimation. A similar procedure was used in an earlier report [13], where R/S values for ALS-inhibitor resistanr A. palmeri and A. spinosus $\mathrm{L}$. (spiny amaranth) were calculated based on inferred data. Thus, the R/S values of the PA-R accession were $>72,>933$, and $>78$ for pyrithiobac, imazaquin, and trifloxysulfuron, respectively.

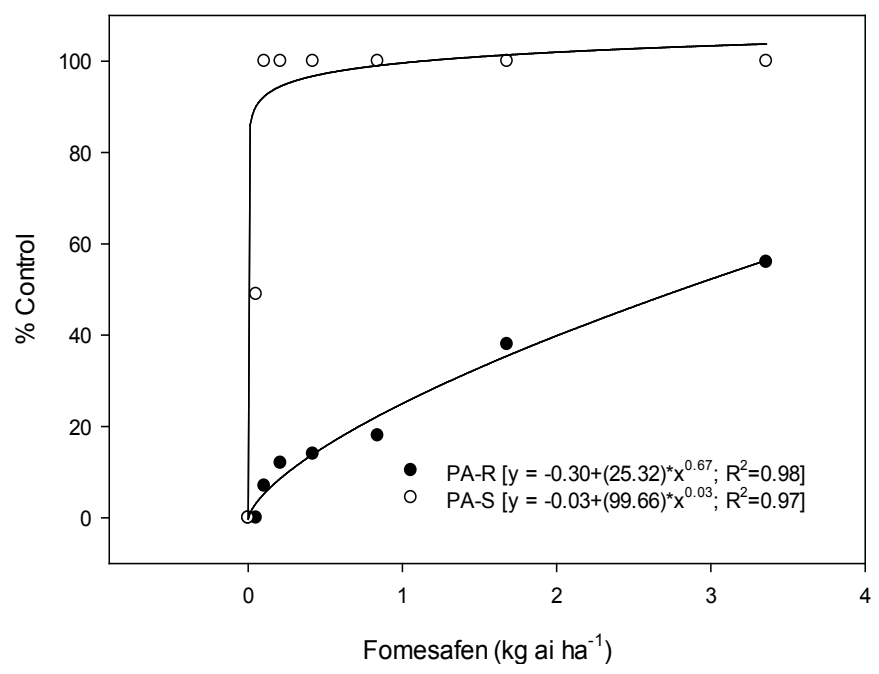

Figure 1. Fomesafen dose response as \% control of resistant PA-R and susceptible PA-S A. palmeri plants 3 WAT. 


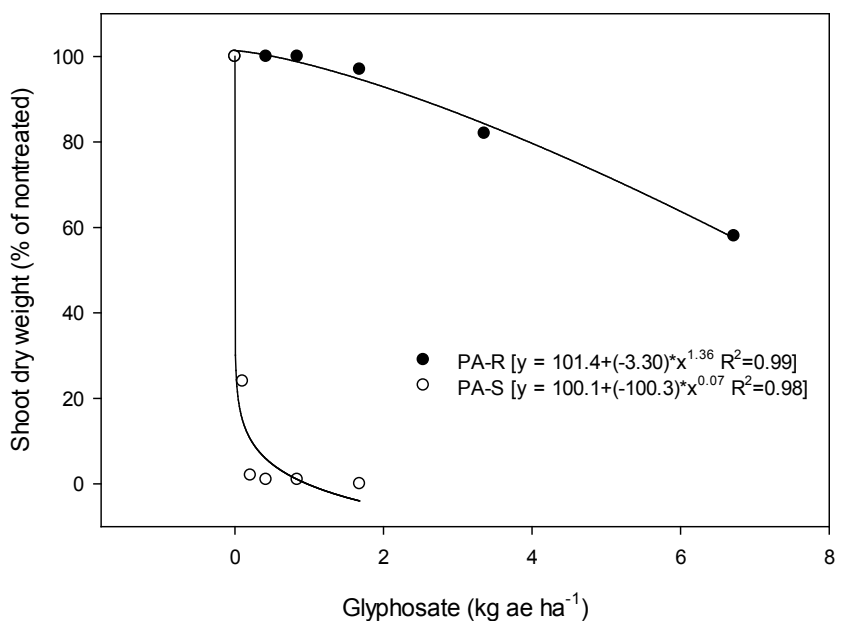

Figure 2. Glyphosate dose response as \% shoot dry weight reduction of resistant PA-R and susceptible PA-S A. palmeri plants 3 WAT.

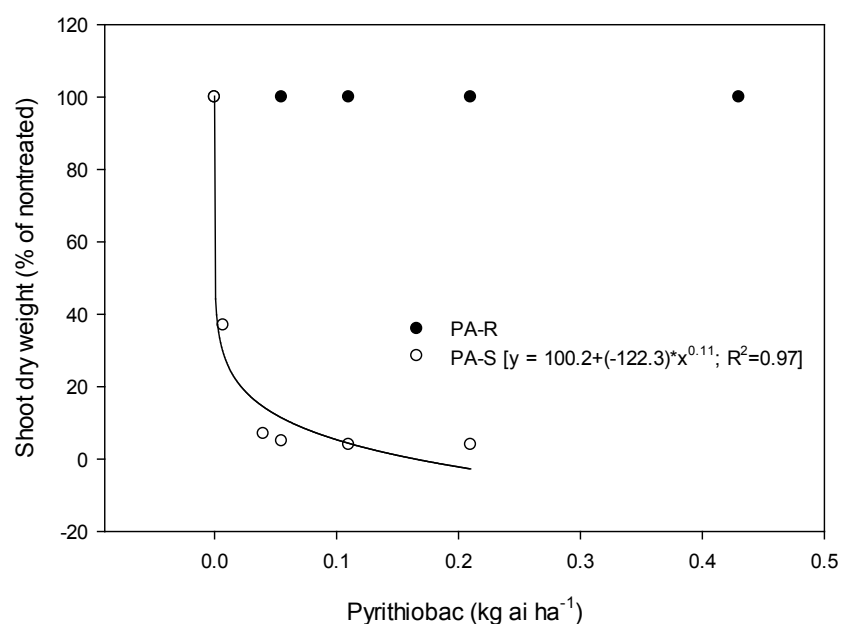

Figure 3. Pyrithiobac dose response as \% shoot dry weight reduction of resistant PA-R and susceptible PA-S A. palmeri plants 3 WAT.

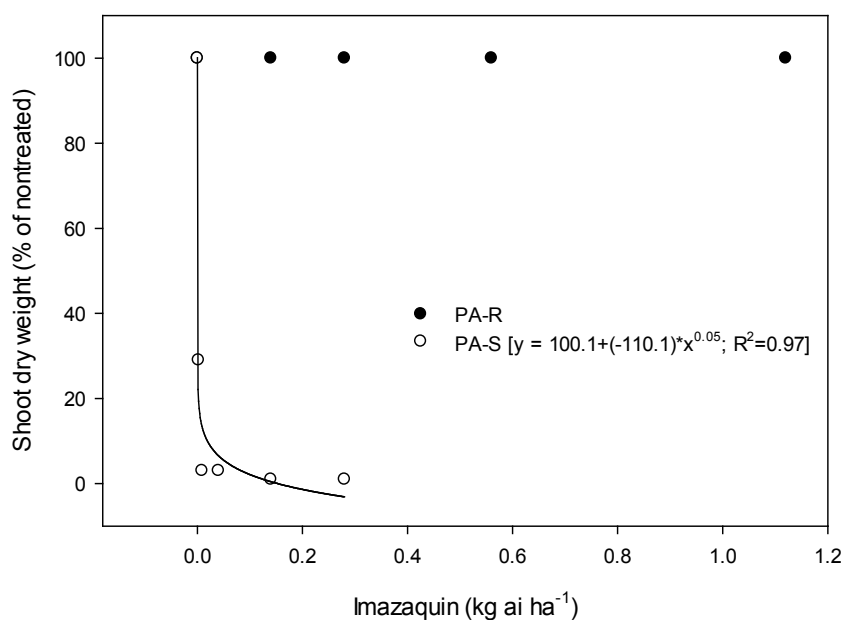

Figure 4. Imazaquin dose response as \% shoot dry weight reduction of resistant PA-R and susceptible PA-S A. palmeri plants 3 WAT. 


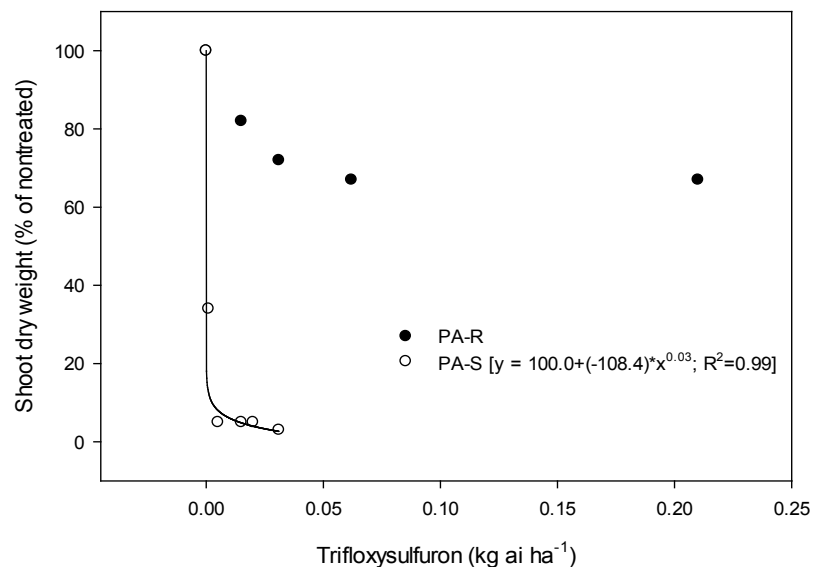

Figure 5. Trifloxysulfuron dose response as \% shoot dry weight reduction of resistant PA-R and susceptible PA-S A. palmeri plants 3 WAT.

\subsection{Cross Resistance to PPO Inhibitors}

Both PA-R and PA-S accessions were controlled $100 \%$ by flumioxazin, fomesafen and oxyfluorfen, all applied PRE, thereby indicating lack of any cross-resistance in the PA-R accession (Table 1). A PRE dose-response study that includes doses less and more than the respective herbicide doses used for flumioxazin, fomesafen, and oxyfluorfen would provide a better understanding of resistance to herbicides applied PRE. Several PPO inhibiting herbicides applied POST were ineffective in controlling the PA-R accession, except saflufenacil (Table 1). Acifluorfen, lactofen, carfentrazone, and sulfentrazone provided $63 \%, 6 \%, 52 \%$, and $18 \%$ control, respectively, of PA-R plants, while saflufenacil provided $95 \%$ control. PA-S plants were completely controlled by all herbicides evaluated. The above results indicate the PA-R accession is cross-resistant to selected herbicides applied POST, but not to some when treated PRE.

\subsection{Molecular Sequence Analysis and Resistance Mechanisms}

Only 3 (all heterozygous) of 10 PA-R plants tested positive for a mutation leading to the deletion of glycine at codon $210(\triangle \mathrm{G} 210)$ of PPO2 gene (data not shown) (10). No point mutations were detected at the 106 locus of EPSPS in the PA-R plants; they had 22 - 87 more copies of EPSPS compared to the PA-S plants (data not shown). Molecular analysis of the ALS gene from 8 PA-R plants indicated the presence of point mutations leading to single nucleotide substitutions at codons $197,377,574$, and 653, resulting in proline-to-serine, arginine-to-glutamine, tryptophan-to-leucine, and serine-to-asparagine replacements, respectively (Table 2).

The above results from molecular sequence analysis indicate that the PA-R accession has target-site based resistance mechanisms to multiple herbicide modes of action, i.e., altered target site for ALS and PPO inhibitor resistance and gene amplification for glyphosate resistance. Similar results of target-site based resistance to PPO inhibitors and multiple resistance to ALS and PPO inhibitors and glyphosate were reported in A. palmeri populations from Arkansas and Indiana, respectively [14] [15]. 
Table 1. Control of PA-R A. palmeri accession with selected PPO inhibiting herbicides applied PRE and POST.

\begin{tabular}{cccc}
\hline Herbicide & Timing $^{\mathrm{a}}$ & Control $^{\mathrm{b}}$ & $\%$ \\
\hline & & $100 \mathrm{a}$ & $100 \mathrm{a}$ \\
\hline Flumioxazin & PRE & $100 \mathrm{a}$ & $63 \mathrm{~b}$ \\
Fomesafen & PRE & 6 \\
Oxyfluorfen & PRE & POST & $52 \mathrm{~b}$ \\
Acifluorfen & POST & 18 \\
Lactofen & POST & $95 \mathrm{a}$ \\
Carfentrazone & POST & POST & \\
Sulfentrazone & & \\
\hline
\end{tabular}

${ }^{a} \mathrm{PRE}$, preemergence; POST, postemergence. ${ }^{\mathrm{b}}$ Means followed by different letters are significantly different from each other within timing according to Fisher's protected $\mathrm{LSD}$ at $\mathrm{P}=0.05$.

Table 2. Codons and amino acids at eight loci (with known point mutations) of the ALS gene in 8 PA-R and 2 PA-S plants.

\begin{tabular}{|c|c|c|c|c|c|c|c|c|}
\hline Codins: & & & & & & & & \\
\hline & Ala122 & Pro197 & Ala205 & Asp376 & Arg377 & $\operatorname{Trp} 574$ & Ser653 & Gly654 \\
\hline $\mathrm{R} 1$ & GCA & $\mathrm{CCC}$ & GCT & GAT & CGA/CCA & TGG/TTG & AGC & GGC \\
\hline $\mathrm{R} 2$ & GCA & $\mathrm{CCC}$ & GCT & GAT & CGA & TGG & AGC & GGC \\
\hline R3 & GCA & $\mathrm{CCC}$ & GCT & GAT & CGA/CGT & TGG & AGC/AAC & GGC \\
\hline R6 & GCA & $\mathrm{CCC}$ & GCT & GAT & CGA & TGG & AGC & GGC \\
\hline R7 & GCA & $\mathrm{CCC}$ & GCT & GAT & CGA & TGG/TTG & AGC & GGC \\
\hline $\mathrm{R} 8$ & GCA & $\mathrm{CCC}$ & GCT & GAT & CGA & TGG & AGC & GGC \\
\hline R9 & GCA & $\mathrm{CCC}$ & GCT & GAT & CGA & TGG & AGC/AAC & GGC \\
\hline R10 & GCA & CCC/TCC & GCT & GAT & CGA/CAA & TGG & AGC & GGC \\
\hline S1 & GCA & $\mathrm{CCC}$ & GCT & GAT & CGA & TGG & AGC & GGC \\
\hline S2 & GCA & $\mathrm{CCC}$ & GCT & GAT & CGA & TGG & AGC & GGC/GGT \\
\hline \multicolumn{9}{|c|}{ Amino acids: } \\
\hline $\mathrm{R} 1$ & A & $\mathrm{P}$ & A & $\mathrm{D}$ & $\mathrm{R} / \mathrm{P}$ & $\mathrm{W} / \mathrm{L}$ & S & G \\
\hline $\mathrm{R} 2$ & A & $\mathrm{P}$ & A & $\mathrm{D}$ & $\mathrm{R}$ & $\mathrm{W}$ & S & G \\
\hline R3 & A & $\mathrm{P}$ & A & $\mathrm{D}$ & $\mathrm{R}$ & $\mathrm{W}$ & $\mathrm{S} / \mathrm{N}$ & G \\
\hline R6 & A & $\mathrm{P}$ & A & $\mathrm{D}$ & $\mathrm{R}$ & $\mathrm{W}$ & $S$ & $\mathrm{G}$ \\
\hline R7 & A & $\mathrm{P}$ & A & $\mathrm{D}$ & $\mathrm{R}$ & $\mathrm{W} / \mathrm{L}$ & $S$ & G \\
\hline $\mathrm{R} 8$ & A & $\mathrm{P}$ & A & $\mathrm{D}$ & $\mathrm{R}$ & W & $S$ & G \\
\hline R9 & A & $\mathrm{P}$ & A & $\mathrm{D}$ & $\mathrm{R}$ & $\mathrm{W}$ & $\mathrm{S} / \mathrm{N}$ & G \\
\hline R10 & A & $\mathrm{P} / \mathrm{S}$ & A & $\mathrm{D}$ & $\mathrm{R} / \mathrm{Q}$ & W & $S$ & G \\
\hline S1 & A & $\mathrm{P}$ & A & $\mathrm{D}$ & $\mathrm{R}$ & W & $S$ & G \\
\hline S2 & A & $\mathrm{P}$ & A & $\mathrm{D}$ & $\mathrm{R}$ & $\mathrm{W}$ & $S$ & G \\
\hline
\end{tabular}




\section{Conclusion}

Growers in Mississippi and across the United States must implement short- and long-term integrated herbicide resistance management practices comprising chemical, mechanical, and cultural strategies to combat multiple herbicide resistant $A$. palmeri populations such as the one reported here. Short-term control methods may include targeted spraying of resistant plants with drones equipped with precision sprayers. Long-term practices could include implementation of cover crops, crop rotation, modified row spacing, and remote sensing-hyperspectral imaging technologies.

\section{Conflicts of Interest}

The authors declare no conflicts of interest regarding the publication of this paper.

\section{References}

[1] Heap, I.M. (2020) International Survey of Herbicide Resistant Weeds. http://weedscience.org

[2] Mallory-Smith, C.A., Thill, D.C. and Dial, M.J. (1990) Identification of Sulfonylurea Herbicide-Resistant Prickly Lettuce (Lactuca serriola). Weed Technology, 4, 163-168. https://doi.org/10.1017/S0890037X00025173

[3] Primiani, M., Cotterman, M.J.C. and Saari, L.L. (1990) Resistance of Kochia (Kochia scoparia) to Sulfonylurea and Imidazolinone Herbicides. Weed Technology, 4, 169-172. https://doi.org/10.1017/S0890037X00025185

[4] Tranel, P.J. and Wright, T.R. (2002) Resistance of Weeds to ALS-Inhibiting Herbicides: What Have We Learned? Weed Science, 50, 700-712. https://doi.org/10.1614/0043-1745(2002)050[0700:RROWTA]2.0.CO;2

[5] Sosnoskie, L.M., Kichler, J.M., Wallace, R.D. and Culpepper, A.S. (2011) Multiple Resistance in Palmer Amaranth to Glyphosate and Pyrithiobac Confirmed in Georgia. Weed Science, 59, 321-325. https://doi.org/10.1614/WS-D-10-00132.1

[6] Nandula, V.K., Reddy, K.N., Koger, C.H., Poston, D.H., Rimando, A.M., Duke, S.O., Bond, J.A. and Ribeiro, D.N. (2012) Multiple Resistance to Glyphosate and Pyrithiobac in Palmer Amaranth (Amaranthus palmeri) from Mississippi and Response to Flumiclorac. Weed Science, 60, 179-188. https://doi.org/10.1614/WS-D-11-00157.1

[7] Patzoldt, W.L., Hager, A.G., McCormick, J.S. and Tranel, P.J. (2006) A Codon Deletion Confers Resistance to Herbicides Inhibiting Protoporphyrinogen Oxidase. Proceedings National Academy of Sciences, 103, 12329-12334. https://doi.org/10.1073/pnas.0603137103

[8] Hoagland, R.E., Jordan, R.H. and Teaster, N.D. (2013) Bioassay and Characterization of Several Palmer Amaranth Biotypes with Varying Tolerances to Glyphosate. American Journal of Plant Sciences, 4, 1029-1037. https://doi.org/10.4236/ajps.2013.45127

[9] Doyle, J.J. and Doyle, J.L. (1987) A Rapid DNA Isolation Procedure for Small Quantities of Fresh Leaf Tissue. Phytochemical Bulletin, 19, 11-15.

[10] Wuerffel, R.J., Young J.M., Lee, R.M., Tranel, P.J., Lightfoot, D.A. and Young, B.G. (2015) Distribution of the $\Delta$ G210 Protoporphyrinogen Oxidase Mutation in Illinois Waterhemp (Amaranthus tuberculatus) and an Improved Molecular Method for 
Detection. Weed Science, 63, 839-845. https://doi.org/10.1614/WS-D-15-00037.1

[11] Giacomini, D.A., Umphres, A.M., Nie, H., Mueller, T.C., Steckel, L.E., Young, B.G., Scott, R.C. and Tranel, P.J. (2017) Two New PPX2 Mutations Associated with Resistance to PPO-Inhibiting Herbicides in Amaranthus palmeri. Pest Management Science, 73, 1559-1563. https://doi.org/10.1002/ps.4581

[12] Chatham, L.A., Wu, C., Riggins, C.W., Hager, A.G., Young, B.G., Roskamp, G.K. and Tranel, P.J. (2015) EPSPS Gene Amplification Is Present in the Majority of Glyphosate-Resistant Illinois Waterhemp (Amaranthus tuberculatus) Populations. Weed Technology, 29, 48-55. https://doi.org/10.1614/WT-D-14-00064.1

[13] Molin, W.T., Nandula, V.K., Wright, A.A. and Bond, J.A. (2016) Transfer and Expression of ALS Inhibitor Resistance from Palmer Amaranth (Amaranthus palmeri) to an $A$. spinosus $\times$ A. palmeri Hybrid. Weed Science, 64, 240-247.

https://doi.org/10.1614/WS-D-15-00172.1

[14] Salas, R.A., Burgos, N.R., Tranel, P.J., Singh, S., Glasgow, L., Scott, R.C. and Nichols, R.L. (2016) Resistance to PPO-Inhibiting Herbicide in Palmer Amaranth from Arkansas. Pest Management Science, 72, 864-869. https://doi.org/10.1002/ps.4241

[15] Spaunhorst, D.J., Nie, H., Todd, J.R., Young, J.M., Young, B.G. and Johnson, W.G. (2019) Confirmation of Herbicide Resistance Mutations Trp574Leu, $\Delta$ G210, and EPSPS Gene Amplification and Control of Multiple Herbicide-Resistant Palmer Amaranth (Amaranthus palmeri) with Chlorimuron-ethyl, Fomesafen, and Glyphosate. PLoS ONE, 14, e0214458. https://doi.org/10.1371/journal.pone.0214458 